\title{
KONSEP NEGARA KEPULAUAN DALAM UPAYA PERLINDUNGAN WILAYAH PENGELOLAAN PERIKANAN INDONESIA
}

\author{
Amiek Soemarmi*, Erlyn Indarti, Pujiyono, Amalia Diamantina \\ Fakultas Hukum, Universitas Diponegoro \\ Jl. Prof. Soedarto, S.H, Tembalang Semarang \\ amiek_hk@yahoo.com
}

\begin{abstract}
Indonesia is an archipelago characterized by the archipelago with territories whose rights and rights are regulated by law. The implementation of the concept of an archipelago in the effort to protect fisheries in Indonesia is a problem in this article. The purpose of this study was to determine the implementation of the concept of the archipelago of the Republic of Indonesia in regulating fisheries management areas where there were foreign fishing vessels entering Indonesian fisheries causing losses to fishing vessels. The method of normative and descriptive analytical juridical approach used in the study was supported by case studies of capture area conflicts both in Indonesian fisheries catchment areas which bordered fisheries management areas in other countries. The results of the study obtained that the Indonesian state regulates through regulation of fishing areas nationally and internationally through agreements or cooperation with other countries as an effort to protect Indonesian fishermen.
\end{abstract}

Keywords: Archipelagic State; Indonesian Territory; Fisheries Management Areas

\begin{abstract}
Abstrak
Indonesia adalah negara kepulauan yang berciri Nusantara dengan wilayah yang batas dan haknya diatur dengan Undang-undang. Implementasi konsep negara kepulauan dalam upaya perlindungan perikanan di Indonesia yang menjadi permasalahan dalam artikel ini. Tujuan penelitian ini untuk mengetahui implementasi konsep negara kepulauan Republik Indonesia dalam mengatur wilayah pengelolaan perikanan dimana terdapat kapal-kapal ikan asing yang masuk di wilayah perikanan Indonesia mengakibatkan kerugian bagi kapal ikan. Metode pendekatan yuridis normatif dan deskriptif analisis digunakan dalam penelitian didukung studi kasus konflik wilayah tangkap baik di wilayah tangkap perikanan Indonesia yang berbatasan dengan wilayah pengelolaan perikanan negara lain. Hasil penelitian diperoleh bahwa negara Indonesia mengatur melalui regulasi wilayah penangkapan ikan secara nasional dan internasional melalui perjanjian atau kerjasama dengan negara lain sebagai upaya perlindungan nelayan Indonesia.
\end{abstract}

Kata kunci: Negara Kepulauan; Wilayah Negara; Wilayah Pengelolaan Perikanan

\section{A. Pendahuluan}

Indonesia sebagai negara kepulauan terbesar didunia memiliki dua pertiga dari wilayahnya berupalautan Indonesia yaitu 6,32 (enam koma tiga puluh dua) juta kilometer persegi (km2) (Pudjiastuti, 2016b, p. 4), 17.504 (tujuh belas ribu lima ratus empat) pulau-pulau (Pudjiastuti, 2016b, p. 4), dan merupakan salah satu negara yang memiliki garis pantai terpanjang kedua di dunia setelah Kanada yaitu 99.093 (Sembilan puluh Sembilan ribu semilan puluh tiga kilometer persegi (km2) (Pudjiastuti, 2016b, p. 4). Di samping itu secara geografis Indonesia terletak di antara dua benua yaitu Benua Asia dan Benua Australia dan dua samudera yaitu 
Samudera Hindia dan Samudera Pasifik yang merupakan kawasan paling dinamis dalam percaturan, baik secara ekonomis maupun politik. Letak geografis yang strategis tersebut menjadikan Indonesia memiliki keunggulan serta sekaligus serta ketergantungan yang tinggi terhadap kelautan.

Indonesia sebagai negara kepulauan yang sebagian besar wilayahnya perairan banyak terdapat selat-selat.Salah satu selat di Indonesia yang juga merupakan selat yang terkenal di dunia internasional yaitu Selat Malaka. Selat Malaka adalah sebuah selat yang terletak diantara Semenanjung Malaysia (Thailand, Malaysia, Singapore) dan Pulau Sumatera (Indonesia). Selat Malaka mempunyai peranan penting bagi dunia internasional karena letaknya stategis. Selat Malaka merupakan salah satu jalur pelayaran terpenting didunia, sama pentingnya Terusan Suez atau terusan Panama.

Di samping keunggulan yang bersifat komparatif berdasarkan letak geografis, potensi sumber daya alam di wilayah laut mengandung sumber daya hayati atau non hayati yang sangat bermanfaat bagi kelangsungan hidup masyarakat. Potensi tersebut dapat diperoleh dari dasar laut dan tanah dibawahnya, kolom air dan permukaan laut, termasuk wilayah pesisir dan pulau-pulau kecil sangat logis jika ekonomi kelautan dijadikan tumpuan bagi pembangunan ekonomi nasional. Oleh karena itu laut Indonesia harus dikelola, dijaga dan dimanfaatkan serta dilestarikan oleh masyarakat Indonesia sesuai dengan yang diamanatkan Pasal 33 Undang-Undang Dasar Negara Republik Indonesia Tahun 1945.

Komitmen Presiden Indonesia menjadikan Indonesia sebagai poros maritim dunia tentu saja harus dimulai dengan menjadikan Indonesia sebagai negara yang dapat memanfaatkan laut secara mandiri dan bertanggung jawab. Salah satu diantaranya adalah membuat sektor kelautan dan perikanan menjadi salah satu prioritas pembangunan Indonesia , demi tercapainya salah satu pilar sebagai poros maritim dunia yaitu tercapainya kedaulatan pangan laut (Pudjiastuti, 2016b, p. 5). Sejak dilantik sebagai Presiden Republik
Indonesia Bapak H. Joko Widodo telah menegaskan bahwa masa depan bangsa Indonesia ada di lautan, dan hal ini dinyatakan dalam komitmennya pada pidato kenegaraan tanggal 20 Oktober 2014 (Pudjiastuti, 2016b, p. 5).

Sebagaimana diketahui bahwa tanggal 7 April 2011 Kapal Hiu 001 milik petugas patroli Kementerian Kelautan dan Perikanan (KKP) mengidentifikasikan ada dua kapal berbendera Malaysia sedang menangkap ikan di kawasan Zona Ekonomi Eksklusif (selanjutnya disingkat ZEE) Indonesia di Selat Malaka. Setelah kedua kapal ditangkap dan digiring ke pelabuhan Belawan, di tengah jalan ada tiga helikopter Malaysia yang menghalangi kapal milik petugas patroli Indonesia.Petugas di dalam Helikopter Malaysia itu meminta supaya kedua kapal dilepas karena menurut kapal itu masih berada di kawasan Zona Ekonomi Eksklusif (selanjutnya disebut ZEE) Malaysia.Adanya peristiwa tersebut yang telah terjadi yaitu ditangkapnya dua kapal berbendera Malaysia sedang menangkap ikan di ZEE Indonesia di Selat Malaka, merupakan masalah yang harus segera diselesaikan. Hal ini dikarenakan negara Indonesia dengan negara Malaysia adalah negara tetangga dimana seharusnya terjalin hubungan kerja sama yang baik antar kedua negara ini. Selama belum ada kesepakatan mengenai batas ZEE diantara kedua pihak. Undang-undang Nomor 45 tahun 2009 tentang perubahan atas undang-undang nomor 31 tahun 2004 tentang perikanan disebutkan pada pasal 69 bahwa kapal pengawas perikanan berfungsi melaksanakan pengawasan dan penegakan hukum di bidang perikanan dalam wilayah pengelolaan perikanan negara Republik Indonesia. Kapal pengawas perikanan dapat menghentikan, memeriksa, membawa dan menahan kapal yang diduga atau patut diduga melakukan pelanggaran di wilayah pengelolaan perikanan negara Indonesia. Dalam melaksanakan fungsi tersebut pengawas perikanan dapat melakukan tindakan khusus berupa pembakaran dan/atau penenggelaman kapal perikanan yang berbendera asing berdasarkan bukti permulaan yang cukup (Adhitama, 2017). 
Selain itu, wewenang Penyidik Pegawai Negeri Sipil (PPNS) yang diberi wewenang khusus oleh undang-undang dapat melakukan penyidikan tindak pidana di wilayah perairan laut juga secara tegas diatur dalam berbagai peraturan perundangan baik mengenai wilayah perairan laut Indonesia maupun mengenai tindak pidana tertentu di wilayah perairan laut (Gibran, 2017).

Negara Indonesia dan negara Malaysia sama-sama memiliki klaim sendiri mengenai garis batas ZEE negara masingmasing.Indonesia mengklaim garis tengah antara Indonesia (Sumatera) dan semenanjung Malaysia sebagai garis batas ZEE, sedangkan Malaysia menggunakan garis batas landasan kontinen 1969, sebagai garis ZEE. Adanya perbedaan klaim yang menjadi dasar dasar mengenai batas wilayah bagi masing-masing negara, maka masalah tumpang tindih/Overlapping claim area belum dapat terselesaikan.

Berdasarkan pasal 5 ayat (1) UU Nomor 31 Tahun 2004 tentang Perikanan, Wilayah Pengelolaan Perikanan meliputi : Perairan Indonesia ; Zona Ekonomi Eksklusif Indonesia (ZEEI) dan sungai, danau, waduk, rawa dan genangan air lainnya yang dapat diusahakan serta lahan pembudidayaan ikan yang potensial di wilayah Republik Indonesia. Selanjutnya di dalam pasal 5 ayat (2) disebutkan bahwa pengelolaan perikanan di luar wilayah pengelolaan perikanan Republik Indonesia, sebagaimana dimaksud pada ayat (1) diselenggarakan berdasarkan peraturanperaturan perundang-undangan, persyaratan dan atau standar internasional yang diterima secara umum baik melalui Konvensi I Hukum Laut Jenewa 1958, Undang-Undang Nomor 4 PRP. Tahun 1960 tentang Perairan Indonesia yang sekarang menjadi Undang-Undang Nomor 6 Tahun 1996 dan pengesahan Konvensi PBB melalui Undang-Undang Nomor 17 Tahun 1985 maka Negara Indonesia berubah statusnya menjadi negara kepulauan (Tahar, 2015). Berdasarkan latar belakang tersebut, penulis ingin mengkaji bagaimana implementasi Konsep Negara Kepulauan Indonesia dalam perlindungan Wilayah Pengelolaan Perikanan (WPP)?

\section{B. Pembahasan}

\section{Lahirnya Konsep Negara Kepulauan}

Dalam Ensiklopedia Umum yang dimaksud dengan wilayah negara adalah bagian muka bumi daerah tempat tinggal, tempat hidup dan sumber-sumber hidup warrganegara dari negara tersebut.Wilayah negara terdiri tanah, air (sungai dan laut) dan udara.Pada dasarnya semua sungai dan danau dibagian wilayah tanahnya termasuk wilayah negara (Ensiklopedia Umum, 1973).

Proklamasi kemerdekaan 17 Agustus 1945, merupakan pernyataan kehendak untuk merdeka juga merupakan pernyataan tegaknya eksistensi Indonesia sebagai suatu negara berdasar fakta alamiah dan dikuatkan oleh kenyataan sejarah yang mempunyai tata gambaran wilayah sebagai satu gugusan kepulauan atau satu kawasan Nusantara.

Faktor wilayah merupakan salah satu sendi eksistensi yang esensial bagi negara, walaupun dalam naskah Undang-Undang Dasar 1945 itu sendiri tidak tertuang secara terperinci masalah wilayah negara, namun hal ini mendapat penegasan dalam Pembukaan Undang-Undang Dasar 1945 yang menyatakan "mengantarkan rakyat Indonesia ke depan pintu gerbang kemerdekaan negara Indonesia yang merdeka, bersatu, berdaulat" dan "yang melindungi segenap bangsa Indonesia dan seluruh tumpah darah Indonesia". Kemudian dalam UUDNRI Tahun 1945 barulah diatur dalam Bab IX A mengenai Wilayah Negara, pada pasal 25 A dinyatakan bahwa Negara Republik Indonesia adalah sebuah negara kepulauan yang berciri Nusantara dengan wilayah yang batas-batas dan hak-haknya ditetapkan dengan Undang-undang.

Menurut Pasal 1 Konvensi Montevideo 1933, sebagai negara yang utuh harus mempunyai empat unsur konstitutif sebagai berikut (Samidjo, 1977); harus ada penghuni (rakyat, penduduk, warga atau negara) ( $a$ permanent population), harus ada wilayah atau lingkungan kekuasaan (a defined territory), harus ada kekuasaan tertinggi (penguasa yang berdaulat), pemerintah yang berdaulat ( $a$ government), kesanggupan berhubungan dengan negara- negara lainnya (a capacity to 
enterinto relation with other states ); dan adanya pengakuan (deklaratif).

Jika melihat pemahaman dansyarat-syarat berdirinya sebuah negara, sudah pasti negara Kesatuan Republik Indonesia adalah sebuah negara yang utuh, dalam hal ini M.Yamin berpendapat bahwa keempat syarat konstitutif telah dipenuhi oleh Indonesia sebagaimana tercantum dalam kata-kata Pembukaan UUD RI yang disalin dari Piagam Djakarta 22 Juni 1945 yaitu : (1) bangsa Indonesia (2) tumpah darah Indonesia; (3) pemerintah negara Indonesia; (4) tujuan negara untuk kebahagiaan Indonesia dan dunia (Yamin, n.d.).

Cita-cita kemerdekaan negara Indonesia diawali dengan Proklamasi serta dipertegas dalam Pembukaan Undang-Undang Dasar (UUD) 1945 untuk membentuk suatu negara merdeka yang bersatu merupakan suatu peneguhan konstitusinal tentang cita-cita mendirikan negara.Penggunaan istilah "bersatu" menunjuk pada pengertian tidak terpecah-pecahnya atau terpisah-pisahnya unsur negara yang merupakan eksistensi Negara Republik Indonesia. Konsekuensinya secara yuridis wilayah Negara Indonesia sebagai salah satu unsur "state hood" yang esensial bagi bagi terjaminnya kelangsungan hidup menjadi satu kesatuan yang tidak dapat dipisahkan, sebagai satu negara yang memiliki trimatra, yaitu matra darat, laut dan udara, maka tidak tepat apabila bagian-bagian wilayah negara yang demikian itu "dipisahkan" satu dengan yang lain, karena hal itu bukan yang dimaksud oleh Proklamasi Kemerdekaan Negara Indonesia pada 17 Agustus 1945.

Indonesia dalam upaya menjamin kepentingan rakyat, dengan berpendirian bahwa Indonesia merupakan satu kesatuan (unit) dan lautan di antara pulau-pulau merupakan bagian yang tidak terpisah dari bagian darat Indonesia, melalui Deklarasi Djuanda pada tanggal 13 Desember 1957, dimaksudkan untuk menyatukan wilayah daratan yang terpisah-pisah, segala perairan diantara dan di sekitar pulau-pulau bagian dari wilayah nasional yang merupakan satu kesatuan yang tidak dapat dipisahkan. Bentuk geografis sebagai negara kepulauan yang terdiri beribu-ribu pulau mempunyai sifat dan corak tersendiri memerlukan pengaturan tersendiri.

Deklarasi Djuanda yang memuat Konsep Negara Kepulauan, pada tanggal 18 Pebruari 1960 dituangkan dalam bentuk Peraturan Pemerintah Pengganti Undang-Undang (Perpu) dan selanjutnya ditingkatkan dalam bentuk Undang-Undang yaitu Undang-Undang Nomor 4/Prp Tahun 1960 tentang Perairan Indonesia, selanjutnya diubah dengan UndangUndang Nomor 6 Tahun 1996 tentang Perairan Indonesia. Undang-Undang tersebut pada hakikatnya merubah cara penetapan laut wilayah selebar 3 mil laut diukur dari garis air surut atau garis air rendah menjadi laut wilayah selebar 12 mil laut diukur dari garis pangkal lurus yang ditarik dari ujung ke ujung, dengan demikian garis pangkal lurus tersebut akan melingkari negara Kepulauan Indonesia. Laut yang terdapat diantara pulau-pulau yang terdapat di dalam garis pangkal lurus tersebut tidak sebagai laut bebas, tetapi telah berubah menjadi perairan kepulauan dan perairan pedalaman yang berada di bawah kedaulatan Indonesia.Penarikan garis pangkal lurus tersebut merupakan penerapan prinsip Negara Kepulauan yang telah diakui oleh Hukum Internasional melalui Putusan Mahkamah Internasional (Juwana, 2003).

Berlakunya peraturan mengenai wilayah perairan Indonesia melalui "Deklarasi Djuanda" maka dengan tegas bahwa Pasal 1 ayat (1) tentang penentuan batas laut territorial berdasarkan Territoriale Zee en Maritieme Kringen Ordonannantie 1939/ TZMKO sudah tidak berlaku lagi, dimana pengaturan tentang laut territorial Indonesia selebar 3 (tiga) mil laut yang tertuang dalam Territorial Zee Maritieme Kringen Ordonantie 1939 / TZMKO (Ordonansi Territorial dan Lingkungan Maritim 1939) tentang wilayah Perairan Indonesia dirasakan tidak cukup lagi untuk menjamin kepentingan rakyat dengan sebaik-baiknya (Kusumaatmadja, 1978).

Deklarasi Djuanda melalui rumusan "Penentuan batas laut territorial yang lebarnya diukur dengan garis yang menghubungkan titik-titik ujung terluar pada pulau-pulau 
Negara Indonesia. Ketentuan tersebut di atas akan diaturselekasnya dengan UndangUndang" (Alinea ke-5 Pengumuman Pemerintah Mengenai Wilayah Perairan Negara Republik Indonesia tahun 1957, 1957). Selanjutnya menurut Mochtar Kusumaatmaja, hanya terdapat satu sarana hukum untuk memenuhi kebutuhan Indonesia dalam memperluas kedaulatannya dan menyatukan wilayah yang semula bercerai berai, yaitu dengan menerapkan prinsip negara kepulauan (archipelago stateprinciple).

Pengertian "negara kepulauan" dalam konsepsi negara kepulauan Indonesia berasal dari pengertian Nusantara. Nusantara berasal dari kata "nusa" yang berarti kumpulan (gugusan) pulau, dan "antara" diartikan suatu tempat yang terletak benua dan di antara diartikan suatu tempat yang terletak atau diapit oleh tempat yang lain. Berdasarkan pengertian tersebut, maka arti "nusantara" yaitu kepulauan yang terletak diantara benua dan diantara samudera. Yang dimaksud dengan benua padawaktu adalah India dan China (The realm of India and the realm of China) (Danusaputra, 1980).

Dalam pengertian sekarang, arti nusantara yaitu kepulauan yang terletak di antara dua benua yaitu Asia dan Australia, serta diantara samudera yaitu Samudera Hindia dan Pasifik.Pengertian negara kepulauan berasal dari pengertian nusantara yang berarti negara yang terdiri dari gugusan pulau. Oleh karena itu, pengertian nusantara sudah menunjukkan konsepsi Negara Kepulauan (Archipelagic State Conception) (Hasbullah, 2001). Perjuangan untuk menjaga kesatuan wilayah Negara kesatuan Republik Indonesia (NKRI) telah dilakukan sejak tahun 1957 melalui Deklarasi Djuanda yang menyatakan wilayah negara Republik Indonesia menggunakan asas negara kepulauan (archipelagic state principle) (Kusumaatmadja, 2015). Deklarasi Djuanda berhasil mengedepankan konsep kesatuan wilayah pulau-pulau dan perairan Indonesia dengan menghubungkan titik-titik terluar dari wilayah Indonesia, serta meletakkan kedaulatan seluruh wilayah nusantara. Konsep ini kemudian diperjuangkan dalam Konferensi Hukum Laut Jenewa 1958 namun tidak berhasil mendapatkan pengakuan internasional, untuk itu Indonesia kembali melakukan "unilateral action" dengan membuat Peraturan Pemerintah Pengganti Undang-undang Nomor 4 Tahun 1960 tentang Perairan Indonesia yang menegaskan Konsep Negara Kepulauan, sampai akhirnya diplomasi Indonesia diakui dalam United Nations Convention on the Law oftheSea (UNCLOS 1982) (Ariadno, 2015).

Berlakunya UNCLOS (United Nations Convention on The Law Of The Sea) yang merupakan Konvensi Perserikatan BangsaBangsa tentang Hukum Laut yang telah diratifikasi melalui Undang-Undang Nomor 17 Tahun 1985 dan berlakunya Undang-Undang Nomor 32 Tahun 2014 tentang Kelautan merupakan salah satu landasanbagi upaya pemerintah untuk menegakkan kedaulatan wilayahIndonesia. Setiap negara memiliki hak untuk menegakkan hukum dan wilayah negaranya, begitupula dengan Indonesia, sebagai negara yang memiliki perairan yang luas yang mengelilingi negaranya. Hal ini merupakan tantangan bagi Indonesia yang sejak tanggal 13 Desember 1957 melalui Pengumuman Pemerintah telah ditandatangani Perdana Menteri Djuanda yang dikenal dengan "Deklarasi Djuanda".

Selanjutnya Pasal 1 angka 1 UndangUndang Nomor 43 Tahun 2008 tentang Wilayah Negara mendefinisikan wilayah negara sebagai salah satu unsurnegara yang merupakan satu kesatuan wilayah daratan, perairan pedalaman, perairan kepulauan dan laut territorial beserta dasar laut dan tanah di bawahnya, serta ruang udara di atasnya, termasuk seluruh sumber kekayaan yang terkandung didalamnya. Berdasarkan definisi tersebut, dapat disimpulkan bahwa wilayah negara adalah tempat tinggal, tempat hidup dan sumber kehidupan warga negara yang meliputi daratan, lautan dan ruang udara, dimana suatu negara memiliki kedaulatan penuh atas wilayah negaranya. Bentuk wilayah negara Indonesia berdasarkan teorinya termasuk divided or separated, yaitu negara yang terpisah oleh wilayah yang dipisahpisahkan / daratan-daratannya dipisah-pisah oleh perairan laut) (Hayati \& Yani, 2007). 


\section{Upaya pengaturan Wilayah Pengelolaan Perikanan}

Wilayah negara yang tumbuh berdasarkan pendekatan sumber daya alam merupakan suatu konsepsi fungsional, karena wilayah yang berkembang menjadi "wilayah" negara tersebut bukan berasal dari kewenangan territorial tetapi berasal dari kewenangan untuk memanfaatkan sumber daya alam di wilayah tersebut.

Banyaknya pulau yang dimiliki oleh Negara Indonesia membuat sulitnya koneksi ke pulau yang jauh dari pusat pemerintahan. Pulau-pulau yang berada dekat dengan negara tetangga akan lebih mudah dan lebih diperhatikan oleh negara tetangga akan lebih mudah dan diperhatikan oleh negara tersebut, sehingga adanya hal ini makin membuat celah antara Indonesia dengan Singapura akan memanfaatkan hal tersebut dan memperluas wilayahnya. Hal ini termasuk pulau-pulau yang berbatasan dengan negara-negara lainnya, seperti Malaysia, Thailand, Vietnam, Philipina, Palau, Papua Nugini, Australia dan Timorleste.

Secara historis, masuknya kapal asing pada sektor perikanan dimulai tahun 1960 saat Indonesia memberlakukan Undang-Undang Nomor 1 Tahun 1967 tentang Penanaman Modal Asing. Hal ini diperkuat dengan penandatanganan Banda Agreement I, II dan III antara Pemerintah Indonesia dengan Pemerintah Jepang pada tahun 1968 - 1979. Memasuki tahun 1980-an, operasi kapal ikan asing di Indonesia semakin diperkuat dengan Undang-Undang Nomor 5 Tahun 1983 tentang Zona Ekonomi Eksklusif Indonesia (ZEEI) dan Undang-Undang Nomor 9 Tahun 1985 tentang Perikanan (sekarang menjadi UU No.31 Tahun 2004 dengan perubahannya UU No.45 Tahun 2009 tentang Perikanan), dimana pada waktu itu (saat berlakunya UU No.9 tahun 1985) memperbolehkan badan hukum asing untuk melakukan usaha perikanan tangkap sepanjang diperbolehkan oleh persetujuan atau hukum internasional yang berlaku. Penafsiran UNCLOS 1982, khususnya mengenai keharusan memberikan hak akses kepada negara lain atas surplus sumber daya ikan di Indonesia.
Perubahan peraturan di bidang perikanan pada tahun 2004 dan 2009membuat aktivitas kapal-kapal ikan asing di wilayah Indonesia semakin marak, khususnya di ZEE Indonesia, bahkan dalam Peraturan Menteri Kelautan dan Perikanan No.30 Tahun 2012 tentang Usaha Perikanan Tangkap di Wilayah Pengelolaan Perikanan - Negara Republik Indonesia, kapal penangkap ikan berukuran di atas 1.000 GT (Gross Ton) dapat langsung membawa ikannya ke luar negeri (Pasal 88 Peraturan Menteri Kelautan dan Perikanan No.30 Tahun 2012 tentang Usaha Perikanan Tangkap di Wilayah Pengelolaan Perikanan Negara Republik Indonesia yang dicabut dengan Peraturan Menteri No.26 Tahun 2013 tentang perubahan atas Peraturan Menteri K, n.d.). Maraknya ekploitasi sumber daya perikanan oleh kapal ikan asing dan kapal ikan eks asing di Indonesia telah menganggu kedaulatan, keberlanjutan ekosistem dan menurunkan kesejahteraan nelayan Indonesia yang seharusnya menjadi tuan di negeri sendiri (Pudjiastuti, 2016a).

Dalam Bab III Pasal 5 Ayat (1) UndangUndang Nomor 31 Tahun 2004 Tentang Perikanan telahdiatur mengenai Wilayah Pengelolaan Perikanan (WPP) bahwa Wilayah Pengelolaan Perikanan Republik Indonesia untuk penangkapan ikan dan/atau pembudidayaan ikan meliputi: 1) Perairan Indonesia (Perairan Pedalaman, Perairan Kepulauan dan Perairan Teritorial yang diatur dalam UU No. 6 Tahun 1996 tentang Perairan Indonesia), 2) ZEEI (diatur dalam UU No.5 Tahun 1983 tentang Zona Ekonomi Eksklusif), 3) Sungai,danau ,waduk, rawa dan genangan air lainnya yang dapat diusahakanserta lahan pembudidayaan ikan yang potensialdi wilayah Republik Indonesia.Selanjutnya disebutkan bahwa wilayah pengelolaan perikanan Republik Indonesia, sebagaimana dimaksud pasal tersebut di atas, diselenggarakan berdasarkan peraturan perundang-undangan, persyaratan, dan/atau standar internasional yang diterima secara umum. Berdasarkan data dari Kementerian Kelautan dan Perikanan terdapat 14 (empat belas) Zona fishing ground di dunia, saat ini hanya 2 (dua) Zona yang 
masih potensial, dan salah satunya adalah di Perairan Indonesia.

Berdasarkan Peraturan Menteri Kelautan dan Perikanan No 18 Tahun 2014 Wilayah Pengelolaan Perikanan Negara Republik Indonesia adalah wilayah pengelolaan untuk penangkapan ikan, pembudidayaan ikan, konservasi, penelitian, dan pengembangan perikanan yang yang meliputi perairan pedalaman, perairan kepulauan, laut teritorial, zona tambahan, dan zona ekonomi eklusif Indonesia. Penetapan Wilayah Pengelolaan Perikanan Negara Republik Indonesia, selanjutnya disebut WPPNRI, dilakukan dalam rangka optimalisasi pengelolaan perikanan. WPPNRI meliputi 11 WPPNRI yaitu: 1). WPPNRI 571 meliputi perairan Selat Malaka dan Laut Andaman,2). WPPNRI 572 meliputi perairan Samudera Hindia sebelah Barat Sumatera dan Selat Sunda, 3). WPPNRI 573 meliputi perairan Samudera Hindia sebelah Selatan Jawa hingga sebelah Selatan Nusa Tenggara, Laut dan Laut Timor bagian Barat, 4). WPPNRI 711, meliputi perairan Selat Karimata, Laut Natuna dan Laut Cina Selatan, 5). WPPNRI 712 meliputi perairan Laut Jawa, 6). WPPNRI 713 meliputi perairan Selat Makasar, Teluk Bone, Laut Flores, dan Laut Bali, 7). WPPNRI 714 meliputi perairan Teluk Tolo, dan Laut Banda, 8). WPPNRI 715 meliputi perairan Teluk Tomini, Laut maluku, Laut Halmahera, Laut Seram dan Teluk Berau, 9). WPPNRI 716 meliputi perairan Laut Sulawesi dan sebelah Utara Pulau Halmahera, 10). WPPNRI 717 meliputi perairan Teluk Cendrawasih dan Samudra Pasific, 11). WPPNRI 718 meliputi perairan Laut Aru, Laut Arafuru, Laut Timor Bagian Timur, nama perairan yang tidak tersebut dalam pembagian WPPNRI tetapi berada di dalam suatu WPPNRI merupakan bagian dari WPPNRI tersebut.

Optimalisasi pengelolaan perikanan seperti dimaksud dalam Permen KP diatas tentunya harus didasarkan pada kedaulatan wilayah negara dan mengacu pada paradigma pembangunan berkelanjutan dinyatakan dalam pasal 33 UUDNRI Tahun 1945, yang mengamanatkan agar perekonomian diselenggarakan berdasarkan prinsip berkelanjutan dan berwawasan lingkungan (Pasal 33 ayat (4) Undang-Undang Dasar Negara Republik Indonesia tahun 1945, n.d.). Selama ini pembangunan konvensional meletakkan ekonomi pada pertumbuhan (growth), dan menempatkan faktor lingkungan hidup atau ekosistem pada posisi yang kurang diperhitungkan (Salim, 2010).

\section{Simpulan}

Implementasi konsep negara kepulauan yang berciri Nusantara diselenggarakan berdasarkan prinsip berkelanjutan dan berwawasan lingkungan, dengan menegakkan pilar kedaulatan negara kepulauan, dalam perlindungan wilayah pengelolaan perikanan Republik Indonesia dilandaskan pada Pasal 25 A dan Pasal 33 ayat (3) UUDNRI Tahun 1945, yang diatur lebih lanjut dengan berbagai aturan pelaksanaan yang terdiri dari beberapa undang -undang dan perubahannya serta pasang surut perlindungan WPPNRI.

\section{DAFTAR PUSTAKA}

Adhitama, I. (2017). Impelentasi kebijakan pelarangan penggunaan alat penangkapan Ikan Pukat Hela (Trawls) dan Pukat Tarik (Seine Nets) di Wilayah Pengelolaan Perikanan Negara Indonesia. Jurnal Pembangunan Dan Kebijakan Publik, $8(2), 15$.

Alinea ke-5 Pengumuman Pemerintah Mengenai Wilayah Perairan Negara Republik Indonesia tahun 1957 (1957). Indonesia.

Ariadno, M. K. (2015). Tantangan Indonesia sebagai Negara Kepulauan Terbesar untuk menjadi Poros Maritim Dunia”, dalam Pidato Pengukuhan Guru Besar. Jakarta: Universitas Indonesia.

Danusaputra, M. (1980). Tata lautan Nusantara Dalam Hukum dan Sejarahnya. Bandung: Binacipta.

Ensiklopedia Umum. (1973). Jakarta: Jajaran Kanisius.

Gibran, M. (2017). Penegakan Hukum Pidana Terhadap Penggunaan Alat Tangkap Ikan Ilegal (Studi Pada Ditpol Air Polda Lampung). Jurnal Ilmu Hukum, 1(2), 5.

Hasbullah, F. S. (2001). Negara Kepulauan 
Indonesia dan Hukum Laut Internasional. Jakarta: Serambi Ilmu Semesta.

Hayati, S., \& Yani, A. (2007). Geografi Politik. Bandung: Refika Aditama.

Juwana, H. (2003). Penyelesaian Sengketa Kepemilikan Pulau Sipadan Dan Ligitan. Jurnal Hukum \& Pembangunan, 33(1), 111.

Kusumaatmadja, M. (1978). Bunga Rampai Hukum Laut. Bandung: Bina Cipta.

Kusumaatmadja, M. (2015). Rekam Jejak Kebangsaan. Jakarta: Kompas.

Pasal 33 ayat (4) Undang-Undang Dasar Negara Republik Indonesia tahun 1945.

Pasal 88 Peraturan Menteri Kelautan dan

Perikanan No.30 Tahun 2012 tentang Usaha Perikanan Tangkap di Wilayah Pengelolaan Perikanan Negara Republik Indonesia yang dicabut dengan Peraturan Menteri No.26 Tahun 2013 tentang perubahan atas Peraturan Menteri K. Indonesia.

Pudjiastuti, S. (2016a). "Pemberantasan Illegal, Unreported, and Unregulated fishing: Menegakkan Kedaulatan dan Menjaga Keberlanjutan untuk kesejahteraan Bangsa Indonesia”, dalam Pidato Penganugerahan Gelar Doktor Honoris Causa dibidang Pembangunan Kelautan dan Perikanan. Semarang: Universitas Diponegoro.
Pudjiastuti, S. (2016b). "Surat Badan Reformasi Geospasial No:B3.4/SESMA/IGD/07/2004 Direktorat Jendral PUM Kementerian Dalam Negeri Republik Indonesia", dalam Pidato Penganugerahan Gelar Doktor Honoris Causa di Bidang Pembangunan Kelautan dan Perikanan. Semarang: Universitas Diponegoro.

Salim, E. (2010). Ekonomi dan Pembangunan Berkelanjutan dalam Pembangunan Berkelanjutan. Jakarta: Kepustakaan Populer Gramedia.

Samidjo, S. (1977). Ilmu Negara. Bandung: Armico.

Tahar, A. M. (2015). Penegakan Hukum di Perairan Indonesia. Hukum Laut Internasional Dalam Perkembangan, Serie Monograf, 3(1), 1.

Yamin, M. (n.d.). Tata Negara Madjapahit. 